Polish Journal of Microbiology

2013, Vol. 62, No 3, 223-235

MINIREVIEW

\title{
Characteristic of Bacteriocines and their Application
}

\author{
TOMASZ M. KARPIŃSKI ${ }^{1 \star}$ and ANNA K. SZKARADKIEWICZ² \\ ${ }^{1}$ Department of Medical Microbiology, University of Medical Sciences in Poznań, Poland \\ ${ }^{2}$ Department of Conservative Dentistry and Periodontology, University of Medical Sciences in Poznań, Poland
}

Submitted 5 June 2013, revised 9 August 2013, accepted 9 August 2013

\begin{abstract}
Bacteriocines are small peptides with anti-bacterial properties. They are produced both by Gram-positive and Gram-negative bacteria. Until now, a few hundred bacteriocines were described. Classification of bacteriocines undergoes continuous alterations, as new developments regarding their structure, amino acid sequence and recognised mechanism of their action are available. Some of bacteriocins (lantibiotics) contain atypical amino acids, such as lantionine (Lan), methyllantionine (MeLan), dehydroalanine (Dha), dehydrobutyrine (Dhb), or D-alanine (D-Ala). The best recognized bacteriocines are produced by lactic acid bacteria, including nisine produced by strains of Lactococcus lactis. These bacteriocines have been recognized to be fully safe for humans. At present, nisine is used in food industry, as a preserving agent. Other lactic acid bacteria bacteriocines and probiotic preparations provide an alternative for antibiotics, and are used in food and in animal feed.
\end{abstract}

Ke y words: Lactobacillus sp., antimicrobial peptides, bacteriocines, enterocines, lactic acid bacteria, lantibiotics

\section{Introduction}

Bacteriocines include low molecular weight peptides exhibiting anti-bacterial properties, which are targeted at species closely related to their producer (Casaus et al., 1997; Cintas et al., 1998). They are produced both by Gram-positive (Lactobacillus, Lactococcus, Streptococcus, Enterococcus, Leuconostoc, Pediococcus, Propionibacterium), and by Gram-negative bacteria (Escherichia coli, Shigella, Serratia, Klebsiella, Pseudomonas) (Cintas et al., 1998; Nes et al., 2007; Oppegård et al., 2007; Cascales et al., 2007). Due to their function and structural similarity bacteriocines belong to the group of anti-bacterial compounds, which also includes defensins (produced by mammals), tionines (produced by plants), mangaines (secreted by frogs) or mellitin (present in bee venom). Until now, a few hundred bacteriocines were described (Bactibase, 2013; Bagel, 2013). Interest in bacteriocines reflects potential application of the metabolites and bacteriocine-forming microbes as natural food preserving agents (DelvesBroughton et al., 1996; de Carvalho et al., 2010).

\section{Bacteriocines of Gram-positive bacteria}

Bacteriocines produced by Gram-positive bacteria were classified for the first time by Klaenhammer in 1993 (Klaenhammer, 1993). Classification of bacte- riocines, including enterocines, undergoes continuous alterations, linked to studies on their structure, amino acid sequence and recognised mechanism of their action. The purpose of this review is to present recent classification of bacteriocines, taking into account, their molecular weight, presence of the YGNGVXC motif, disulphide bridges, activity towards Listeria sp., and sensitivity to temperature (Jack et al., 1995; van Belkum and Stiles, 2000; Franz et al., 2007; Nes et al., 2007).

Class I of bacteriocines produced by Gram-positive bacteria encompasses lantibiotics or thermostable peptides of molecular weight below $5 \mathrm{kDa}$. They undergo postranslational modification and contain atypical amino acids, such as lantionine (Lan), methyllantionine (MeLan), dehydroalanine (Dha), dehydrobutyrine (Dhb), or D-alanine (D-Ala) (Nissen-Meyer et al., 2009). Lantibiotics are divided into two groups: lantibiotics of type A and of type B, each group manifesting distinct structural and functional properties. Type A lantibiotics groups elongated molecules, acting by permeabilization of cytoplasmic membrane in sensitive cells while lantibiotics of type B include globular molecules of a variable manner of action.

The best recognized bacteriocine of class I is nisine (Fig. 1), produced by certain strains of Lactococcus lactis. Nisine manifests a broad range of anti-bacterial activity directed against Gram-positive bacteria, such as Enterococcus, Leuconostoc, Lactococcus, Lactobacillus,

* Corresponding author: T.M. Karpiński, Department of Medical Microbiology, University of Medical Sciences in Poznań, Wieniawskiego 3, str., 61-712, Poznań, Poland; phone: +48 618546138; e-mail: tkarpin@interia.pl 


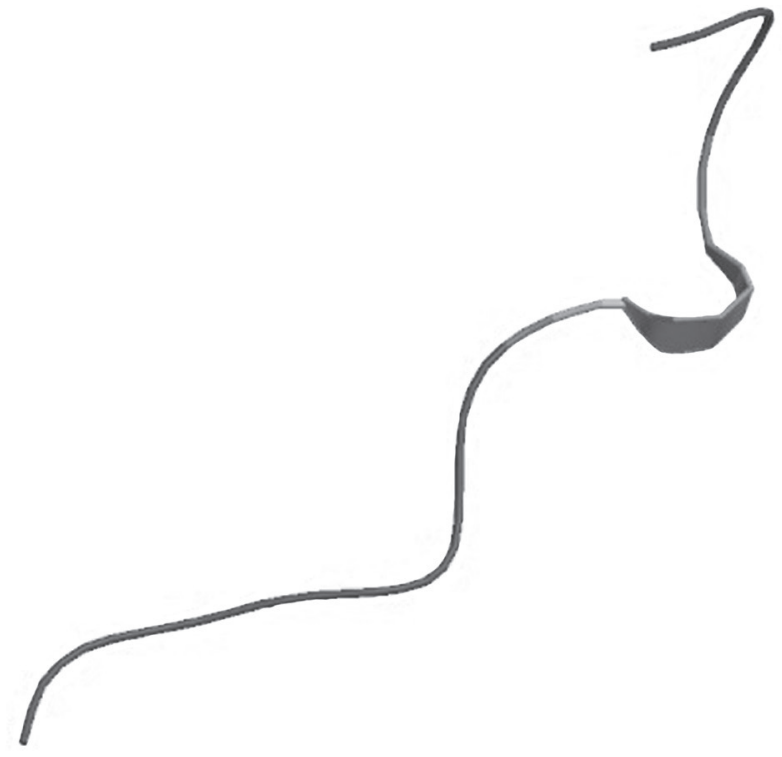

Fig. 1. Tertiary structure of nisine A

(the model generated using I-TASSER server, 2012)

Staphylococcus, Micrococcus, Pediococcus, Listeria. It prevents also against formation of spores and inhibits development of vegetative bacterial cells of Bacillus and Clostridium genera (Delves-Broughton et al., 1996; Cintas et al., 1998; Cheigh and Pyun, 2005).

Class II groups non-lantibiotic bacteriocines, which contain no lantionine. They are thermostable bacteriocines of molecular weight below $10 \mathrm{kDa}$. Bacteriocines of this class do not undergo posttranslational modification. Differences in their structure permitted to distinguish four subclasses. The subclass IIa includes pedicine-like bacteriocines with strong activity against bacteria of Listeria genus. They carry a hydrophilic cationic region with a conserved Tyr-Gly-Asn-Gly-Val$\mathrm{X}$-Cys (YGNGVXC) motif and two cysteins linked by a disulphide bridge (van Belkum and Stiles, 2000; Franz et al., 2007). The bacteriocines of this subclass exhibit high sequence homology (38-80\% identity of amino acid sequences), particularly within the $\mathrm{N}$-terminal region. On the other hand, the $\mathrm{C}$-terminal region is more hydrophobic and differentiated (Casaus et al., 1997; Feng et al., 2009). Common characteristic of subclass IIa bacteriocins is their strong inhibitory activity against the L. monocytogenes (Nishie et al., 2012).

The subclass IIb groups dipeptide bacteriocines. They contain a single disulphide bridge, may contain the N-terminal sequence of Tyr-Gly-Asn-Gly-Val-XCys (van Belkum and Stiles, 2000) or be devoid of it (Franz et al., 2007). Within the subclass IIb investigators distinguish bacteriocines, such as lactococcin $\mathrm{G}$ from L. lactis, lactacin F from Lactobacillus johnsonii, and lactocin 705 from Lactobacillus casei, that require the presence of both peptides for the activity, since separately neither of them manifests antibacterial activity, e.g. (Nissen-Meyer et al., 1992; Allison et al., 1994; Cuozzo et al., 2000; Garneau et al., 2002). The second subgroup of IIb includes bacteriocines in which a single or both peptides manifest activity although their combination increases the activity, e.g. thermophilin 13 from Streptococcus thermophilus, and ABP-118 from Lactobacillus salivarius (Marciset et al., 1997; Flynn et al., 2002).

The subclass IIc groups bacteriocines that are secreted via the Sec pathway, termed the sec-dependent bacteriocines. They contain a single disulphide bridge but they carry no N-terminal sequence of Tyr-Gly-AsnGly-Val-X-Cys (van Belkum and Stiles, 2000; Franz et al., 2007).

The subclass IId encompasses bacteriocines which are distinct in their structure, secretion mechanism and manner of action from bacteriocines classified in subgroups of IIa-IIc. Their example involves enterocines L50 (EntL50A and EntL50B), produced by Enterococcus faecium L50. The EntL50 system resembles dipeptide bacteriocines since the two peptides act synergistically although their sequence shows no similarity to bacteriocines of subclasses IIa-IIc, and they are secreted from their producer with no involvement of the signal peptide (Cintas et al., 1998; Cintas et al., 2000). The subclass IId contains also bacteriocines activated by thiol groups, such as lactococcin B (Venema et al., 1993).

Class III includes bacteriocines of molecular weight above $30 \mathrm{kDa}$. They are thermolabile and are produced mainly by Gram-positive bacteria (van Belkum and Stiles, 2000). The large bacteriocins of Gram-positive bacteria can be further subdivided into two distinct groups: group of the bacteriolytic enzymes (or bacteriolysins), which facilitate the killing of sensitive strains by cell lysis e.g. lysostaphin produced by Staphylococcus aureus and enterolysin A produced by Enterococcus faecalis (Thumm and Gotz, 1997; Nilsen et al., 2003), and group of the non-lytic antimicrobial proteins e.g. helveticin J, produced by Lactobacillus helveticus (Joerger and Klaenhammer, 1986).

Class IV includes bacteriocines which for full activity require presence of a lipid portion or a carbohydrate portion of their molecule (Jack et al., 1995).

Principal characteristics of selected bacteriocines (other than enterocines) are presented in Table 1.

\subsection{Bacteriocines of lactic acid bacteria}

Lactic acid bacteria (LAB) form a non-uniform group with the common property of the ability of anoxic saccharide fermentation. The bacteria include Gram-positive cocci and rods belonging to, Lactobacillus, Lactococcus, Bifidobacterium, Streptococcus, Leuconostoc or Pediococcus genera. The milk fermentation bacteria are able synthesize several antimicrobial substances. In line with bacteriocines, they produce high 
Table I

Basic characteristics of selected backteriocines of Gram-positive bacteria (excluding enterocines)

\begin{tabular}{|c|c|c|c|c|}
\hline $\begin{array}{c}\text { Classes of } \\
\text { bacteriocines }\end{array}$ & Bacteriocine & $\begin{array}{c}\text { Molecular } \\
\text { weight }\end{array}$ & $\begin{array}{l}\text { Producing } \\
\text { strain }\end{array}$ & Activity against bacteria \\
\hline \multirow[t]{5}{*}{ Class I } & $\begin{array}{l}\text { Nisin A (Delves-Broughton et al., 1996; } \\
\text { Cintas et al., 1998; McAuliffe et al., 2001) }\end{array}$ & $5963 \mathrm{Da}$ & $\begin{array}{l}\text { Lactococcus lactis } \\
\text { subsp. lactis }\end{array}$ & $\begin{array}{l}\text { Enterococcus, Lactobacillus, Lactococcus, } \\
\text { Leuconostoc, Listeria, Staphylococcus, } \\
\text { Micrococcus, Pediococcus, Clostridium, } \\
\text { Bacillus (genera) }\end{array}$ \\
\hline & Nisin Z (Mulders et al., 1991) & $5940 \mathrm{Da}$ & $\begin{array}{l}\text { Lactococcus lactis } \\
\text { subsp. lactis }\end{array}$ & $\begin{array}{l}\text { Enterococcus, Lactobacillus, Lactococcus, } \\
\text { Leuconostoc, Listeria, Clostridium }\end{array}$ \\
\hline & Nisin U (Wirawan et al., 2006) & $5863 \mathrm{Da}$ & Lactococcus uberis & $\begin{array}{l}\text { Streptococcus pyogenes, S. uberis, S. agalactiae, } \\
\text { S. dysgalactiae, S. mitis, Staphylococcus } \\
\text { simulans, S. cohnii, Lactococcus lactis, } \\
\text { Lactobacillus acidophilus }\end{array}$ \\
\hline & $\begin{array}{l}\text { Mutacin B-Ny266 } \\
\text { (Mota-Meira et al., 1997) }\end{array}$ & $2425 \mathrm{Da}$ & $\begin{array}{l}\text { Streptococcus } \\
\text { mutans }\end{array}$ & Gram-positive bacteria \\
\hline & $\begin{array}{l}\text { Salivaricin A (Ross et al., 1993; } \\
\text { Wescombe et al., 2006) }\end{array}$ & $2315 \mathrm{Da}$ & $\begin{array}{l}\text { Streptococcus } \\
\text { salivarius }\end{array}$ & Gram-positive bacteria \\
\hline \multirow[t]{6}{*}{$\begin{array}{l}\text { Class II } \\
\text { Subclass IIa }\end{array}$} & $\begin{array}{l}\text { Lactococcin MMFII } \\
\text { (Ferchichi et al., 2001a; 2001b) }\end{array}$ & $4145 \mathrm{Da}$ & Lactococcus lactis & $\begin{array}{l}\text { Enterococcus, Lactobacillus, Lactococcus, } \\
\text { Listeria (genera) }\end{array}$ \\
\hline & $\begin{array}{l}\text { Mesentericin Y105 (Héchard et al., 1992; } \\
\text { Fremaux et al., 1995) }\end{array}$ & $6548 \mathrm{Da}$ & $\begin{array}{l}\text { Leuconostoc } \\
\text { mesenteroides }\end{array}$ & $\begin{array}{l}\text { Lactobacillus, Leuconostoc, Pediococcus, } \\
\text { Listeria (genera) }\end{array}$ \\
\hline & Ubericin A (Heng et al., 2007) & $7681 \mathrm{Da}$ & $\begin{array}{l}\text { Streptococcus } \\
\text { uberis }\end{array}$ & $\begin{array}{l}\text { Listeria sp., Enterococcus faecalis, E. hirae, } \\
\text { Streptococcus bovis, Lactococcus lactis }\end{array}$ \\
\hline & Leucocin A (Hastings et al., 1991) & $3932 \mathrm{Da}$ & $\begin{array}{l}\text { Leuconostoc } \\
\text { gelidum }\end{array}$ & Lactobacillus sp., Listeria monocytogenes \\
\hline & Curvacin A (Tichaczek et al., 1993) & $4327 \mathrm{Da}$ & $\begin{array}{l}\text { Lactobacillus } \\
\text { curvatus }\end{array}$ & $\begin{array}{l}\text { Lactobacillus, Listeria, Enterococcus faecalis } \\
\text { (genera) }\end{array}$ \\
\hline & $\begin{array}{l}\text { Pediocin PA-1 (Lozano et al., 1992; } \\
\text { Rodriguez et al., 2002) }\end{array}$ & $4647 \mathrm{Da}$ & $\begin{array}{l}\text { Pediococcus } \\
\text { acidilactici }\end{array}$ & $\begin{array}{l}\text { Pediococcus, Lactobacillus, Leuconostoc, } \\
\text { Listeria, Bacillus, Enterococcus, Staphylococcus } \\
\text { (genera) }\end{array}$ \\
\hline \multirow[t]{4}{*}{\begin{tabular}{l|} 
Class II \\
Subclass IIb
\end{tabular}} & Lactobin-A (De Vuyst et al., 2004) & $6537 \mathrm{Da}$ & $\begin{array}{l}\text { Lactobacillus } \\
\text { amylovorus }\end{array}$ & Lactobacillus sp. \\
\hline & $\begin{array}{l}\text { Lactacin-F (Alisson et al., 1994; } \\
\text { Contreras et al., 1997; Mollet et al., 2004) }\end{array}$ & $6250 \mathrm{Da}$ & $\begin{array}{l}\text { Lactobacillus } \\
\text { johnsonii }\end{array}$ & Lactobacillus sp., Enterococcus faecalis \\
\hline & Lactocin-705 (Vignolo et al., 1996) & $3376 \mathrm{Da}$ & $\begin{array}{l}\text { Lactobacillus } \\
\text { paracasei }\end{array}$ & Lactobacillus, Listeria, Streptococcus (genera) \\
\hline & Plantaricin F (Diep et al., 1995) & $3722 \mathrm{Da}$ & $\begin{array}{l}\text { Lactobacillus } \\
\text { plantarum }\end{array}$ & Lactobacillus, Pediococcus (genera) \\
\hline \multirow[t]{4}{*}{\begin{tabular}{l|} 
Class II \\
Subclass IIc
\end{tabular}} & $\begin{array}{l}\text { Carnobacteriocin-A (Worobo et al. 1994; } \\
\text { Holck et al., 1994) }\end{array}$ & $7041 \mathrm{Da}$ & $\begin{array}{l}\text { Carnobacterium } \\
\text { piscicola }\end{array}$ & $\begin{array}{l}\text { Carnobacterium sp., Enterococcus sp., Listeria } \\
\text { monocytogenes, Clostridium perfringens }\end{array}$ \\
\hline & Subtilosin A (Shelburne et al., 2007) & $5813 \mathrm{Da}$ & Bacillus subtillis & $\begin{array}{l}\text { Bacillus subtillis, Enterococcus faecalis, } \\
\text { Escherichia coli, Listeria monocytogenes, } \\
\text { Staphylococcus aureus, Streptococcus pyogenes, } \\
\text { Pseudomonas aeruginosa, Porphyromonas } \\
\text { gingivalis, Enterobacter aerogenes, } \\
\text { Shigella sonnei }\end{array}$ \\
\hline & Uberolisin (Wirawan et al., 2007) & $7086 \mathrm{Da}$ & $\begin{array}{l}\text { Streptococcus } \\
\text { uberis strain } 42\end{array}$ & $\begin{array}{l}\text { Enterococcus faecalis, E. hirae, Lactococcus } \\
\text { lactis, Micrococcus luteus, Listeria sp., } \\
\text { Staphylococcus aureus, Streptococcus }\end{array}$ \\
\hline & Acidocin B (Leer et al., 1995) & $5773 \mathrm{Da}$ & $\begin{array}{l}\text { Lactobacillus } \\
\text { acidophilus M46 }\end{array}$ & $\begin{array}{l}\text { Listeria monocytogenes, Lactobacillus sp., } \\
\text { Clostridium sporogenes }\end{array}$ \\
\hline Class III & $\begin{array}{l}\text { Helveticin J } \\
\text { (Joerger and Klaenhammer, 1986) }\end{array}$ & $37512 \mathrm{Da}$ & $\begin{array}{l}\text { Lactobacillus } \\
\text { helveticus }\end{array}$ & Lactobacillus bulgaricus, Lactococcus lactis \\
\hline Class IV & Glycocin F (Venugopal et al., 2011) & $7002 \mathrm{Da}$ & $\begin{array}{l}\text { Lactobacillus } \\
\text { plantarum }\end{array}$ & no data \\
\hline
\end{tabular}


amounts of organic acids (e.g., lactic acid, acetic acid) and other compounds of antimicrobial action, e.g. $\mathrm{H}_{2} \mathrm{O}_{2}$ (Szkaradkiewicz and Karpiński, 2013). LAB are broadly used for production of fermented food, and are responsible for a specific taste and aroma of the products. In parallel, due to production of bacteriocines they protect food from infection by other, often harmful and pathogenic bacteria. The preserving properties of lactic acid bacteria have been known for thousands of years and are broadly applied in food industry (Libudzisz, 2002).

Due to their metabolic activity, lactobacilli form an unfavourable environment for pathogenic bacteria, by producing $\mathrm{pH}$-lowering compounds and bacteriocines in alimentary tract and inhibiting growth of the neighbouring bacteria (Fuller, 1989). Because of their properties, lactobacilli are frequently used in probiotic preparations. The strains of Lactobacillus sp. with confirmed probiotic properties usually belong to the species of Lactobacillus bulgaricus, Lactobacillus acidophilus, Lactobacillus casei, Lactobacillus helveticus, Lactobacillus salivarius and Lactobacillus plantarum (Słońska and Klimuszko, 2010; Klewicka et al., 2011). Due to they probiotic properties, they inhibit growth of several pathogenic microbes, can reduce incidence of traveller's diarrhoea, alleviate the course and shorten duration of some bacterial and viral diarrhoeas (e.g. those induced by Clostridium difficile, Shigella, Salmonella, enterotoxic strains of Escherichia coli or rotaviruses), prevent manifestation or relieve course of post-antibiotic diarrhoeas (Salminen et al., 1998; Pathmakanthan et al., 2000; Rolfe, 2000; Sanders, 2000).

Studies documenting antagonism of probiotic bacteria towards Helicobacter pylori (Coconnier et al., 1998; Andrzejewska and Szkaradkiewicz, 2007) are also of interest. At present, it is known that bacteria of Lactobacillus genus manifest also antagonistic effects toward periodontopathogens, such as Aggregatibacter actinomycetemcomitans, Prevotella intermedia and Porphyromonas gingivalis. Presence of $\mathrm{H}_{2} \mathrm{O}_{2}$-producing strains of Lactobacillus in periodontal pockets prevents against development of chronic periodontitis (Szkaradkiewicz and Stopa, 2008; Szkaradkiewicz et al., 2011; Andrzejewska and Szkaradkiewicz, 2012).

LAB are capable of binding nitrosoamines and certain other mutagenic bacteria, e.g., azo dyes, mycotoxins or amino acid pyrolysates, which corroborates their antineoplastic activity (Rafter, 1995; Burns and Rowland, 2000).

Probiotic bacteria producing bacteriocines are used in dairy industry for the production of cheeses, icecream, yoghurts, kefirs and other fermented soft drinks (Garde et al., 1997; Beshkova and Frengova, 2012). The best known bacteriocine used in food industry is nisine, produced by some strains of Lactococcus. lactis. Nisine, the only bacteriocine of the GRAS status (generally recognized as safe) is used in over forty countries as a conserving agent under the name E234, in meat and dairy products, vegetable and fruit preserves, fish and eggs products (Schillinger et al., 1999). Nisine is easily digested by trypsin and, therefore, it is non-toxic for higher organisms and humans (Piard and Desmazeaud, 1992). Along nisine, some other bacteriocines such as pediocine, bawaricine, piscicoline, jensenine, curvaticine, lacticine and sacacine are of technological/industry significance. In general,bacteriocines synthesized by strains of lactic fermentation bacteria such as Lactococcus sp., Lactobacillus sp., Pediococcus sp., Carnobacterium sp. and Leuconostoc sp. are regarded as safe to use in food preparation. In food products high biostatic activity of bacteriocines is observed in food of low $\mathrm{pH}$ values. This relates to fermented milk products, such as acidic-chymosin cottage cheese, yoghurts and ripening chymosin cottage cheese (Steinka, 2009).

\subsection{Enterocines}

Enterocines represent bacteriocines produced by bacteria of Enterococcus genus. Enterocines exhibit an extensive variability and broad manifestation among isolated obtained from various sources. (Klaenhammer, 1993; Gálvez et al., 1998; Nes et al., 2007). It is suggested that variability of enterocines is a result of genetic exchange between various genera of bacteria, which seems to be confirmed by, e.g., similarity of sequences between enterolysine and staphylococcal lysostaphine or enterocine AS-48 (Fig. 2) and circularine produced by Clostridium beijerinckii (Franz et al., 2007). Enterococci are well known for the presence of multiple mobile genetic elements such as plasmids, or conjugative and non-conjugative transposons. Mechanism of gene transfer may induce a rapid and effective transfer of enterocine encoding genes between enterococci. An excellent example of mobile bacteriocines of clinical significance can be demonstrated by pheromone-inducible conjugative plasmids (Clewell, 1990). On the described plasmids genes encoding cytolysine, bacteriocine 31, enterocine EK97 and enterocine AS-48 were found (Tomita and Clewell, 2000; Tomita et al., 2008). The pheromone-inducible conjugative plasmids may also carry antibiotic resistance genes. Production of bacteriocines may also play a role in colonization of food products by enterococci, dairy and meat products in particular. Several enterocines manifest a broad spectrum of antibacterial activity towards bacteria of Enterococcus, Lactobacillus, Lactococcus, Staphylococcus, Listeria or Clostridium genera (Franz et al., 2007; Nes et al., 2007). Because of this broad target, including Listeria monocytogenes and Clostridium tyrobutyricum, bacteriocine-producing enterococci, as well as isolated bacteriocines, are extensively studied. The goal of these 

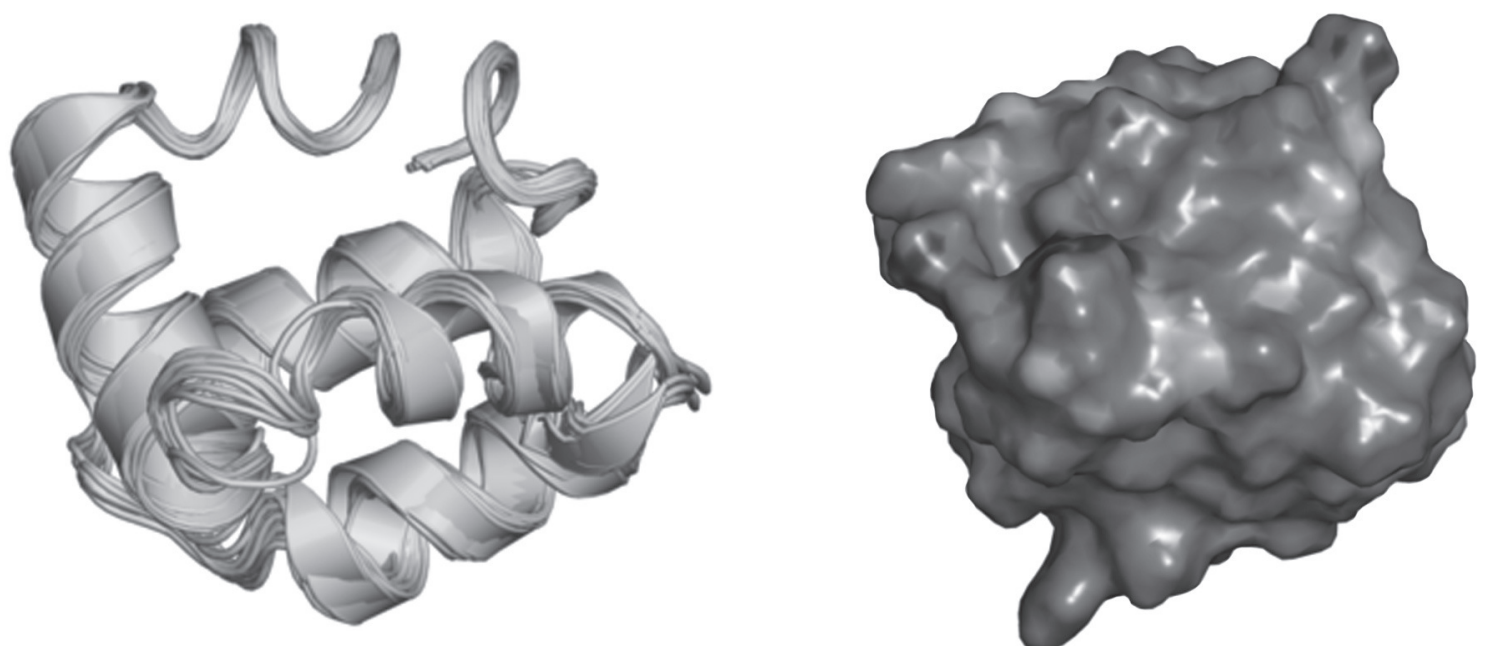

Fig. 2. Tertiary structure of enterocine AS-48 (models generated using the I-TASSER server, 2012)

investigations is mostly related to their application in production of cheese and in fermentation processes (Franz et al., 2007). Table II presents basic characteristics of selected enterocins.

\section{Bacteriocines of Gram-negative bacteria}

Extracellular antibacterial cytotoxins produced by E. coli which reduce competition from other bacterial strains are named colicins and microcins. Spectrum of activity manifested by bacteriocines of Gram-negative bacteria is more narrow than those produced by Grampositive bacteria. Most frequently both the producer and the sensitive strains belong to the same family or to the same species (Šmarda and Šmajs, 1998). Principal characteristics of selected bacteriocines produced by Gram-negative bacteria are presented in Tables III.

The largest group is formed by colicines. They are synthesized by over half of E. coli strains and also by Yersinia pestis (pesticins), Serratia marcescens (marcescins) and by bacteria of genus: Shigella, Klebsiella (klebicins) and Pseudomonas (pyocins) (Cascales et al., 2007). Colicines are large peptides, with molecular weight of $25-80 \mathrm{kDa}$. All colicines are encoded by plasmids Col and their synthesis may be induced using UV rays or mitomycin C. Colicines exhibit antimicrobial activity targeted at closely related bacterial strains, which carry colicin-binding receptor on cell surface and produce no resistance proteins, capable of inactivating colicines (Braun et al., 2002).

The bactericidal action of colicines involves formation of ion channels in the cytoplasmic membrane of sensitive cells, which leads to depolarization of the membrane. Also degradation of peptidoglycan of the cell wall or inhibition of its synthesis may take place. Synthesis and export of colicines are lethal for the producer cells and result in their lysis. The group of genes responsible for colicine activity consists of a gene encoding the toxic protein, resistance-coding gene and, in most of colicines, the gene coding for a protein facilitating colicine export from the cell and inducing lysis of the cell (Šmarda and Šmajs, 1998; Gwiazdowska and Trojanowska, 2005; Cascales et al., 2007). Synthesis of colicines remains under control of a few mechanisms. The principal mechanism involves the SOS system, forming a proportion of gene expression control system involved in DNA repair. In standard conditions synthesis of colicines is switched off in majority of cells and becomes mobilized in stress conditions (Braun et al., 2002).

Microcines, the low molecular weight peptides, manifesting thermostability and a hydrophobic character, form a separate class of bacteriocines produced by Gram-negative bacteria. Microcines are synthesized by E. coli and by a single strain of Klebsiella pneumoniae identified so far (de Lorenzo and Pugsley, 1984; Pons et al., 2002). Based on the mechanism of their action, structure and genetic criteria two classes of microcines can be distinguished. The first class includes peptides of molecular weight $<5 \mathrm{kDa}$, which undergo posttranslational modifications and which attack mainly intracellular structures. The other class encompasses peptides of molecular weight ranging between 7 and $10 \mathrm{kDa}$, which do not undergo posttranslational modifications and which lead to damage and destruction of cell membrane of target cells (Pons et al., 2002; Gwiazdowska and Trojanowska, 2005). In contrast to colicines, synthesis of microcines is not lethal for their producers and is not controlled by the SOS system (Kolter and Moreno, 1992). Microcines are secreted to medium in the late logarythmic phase of growth, except of microcine Mcc E492, which is produced in the early logarythmic phase (de Lorenzo and Pugsley, 1984; Hetz et al., 2002). 
Table II

Basic characteristics of selected enterocines

\begin{tabular}{|c|c|c|c|c|}
\hline $\begin{array}{c}\text { Classes of } \\
\text { bacteriocines }\end{array}$ & Enterocine & $\begin{array}{c}\text { Molecular } \\
\text { weight }\end{array}$ & $\begin{array}{l}\text { Producing } \\
\text { strain }\end{array}$ & Activity against bacteria \\
\hline Class I & $\begin{array}{l}\text { Cytolysin }\left(\mathrm{CylL}_{\mathrm{S}^{\prime \prime}}\right) \\
\text { Cytolysin }\left(\mathrm{CylL}_{\mathrm{L}^{\prime}}\right)\end{array}$ & $3437 \mathrm{Da}$ & $\begin{array}{l}\text { Enterococcus } \\
\text { faecalis } \\
\text { Enterococcus } \\
\text { faecalis }\end{array}$ & $\begin{array}{l}\text { Enterococcus faecalis, Streptococcus, Staphylo- } \\
\text { coccus aureus, S. epidermidis, Lactobacillus } \\
\text { fermentum, L. plantarum, Bacillus cereus, } \\
\text { Clostridium difficile, C. perfringens, } \\
\text { Micrococcus (Cox et al., 2005; Coburn } \\
\text { and Gilmore, 2003; Coburn et al., 2004) }\end{array}$ \\
\hline \multirow[t]{3}{*}{$\begin{array}{l}\text { Class II } \\
\text { Subclass IIa }\end{array}$} & Avicin A (Birri et al., 2009) & $4288 \mathrm{Da}$ & $\begin{array}{l}\text { Enterococcus } \\
\text { avium }\end{array}$ & $\begin{array}{l}\text { Carnobacterium sp., Enterococcus avium, } \\
\text { E. faecalis, E. maldoratus, Lactobacillus } \\
\text { rhamnosus, L. sakei, Leuconostoc lactis, } \\
\text { L. mesenteroides, Listeria innocua, } \\
\text { L. monocytogenes, Pediococcus acidilactici, } \\
\text { P. pentosaceus }\end{array}$ \\
\hline & Enterocin A (Aymerich et al., 1996) & $4851 \mathrm{Da}$ & $\begin{array}{l}\text { Enterococcus } \\
\text { faecium }\end{array}$ & $\begin{array}{l}\text { Enterococcus faecalis, E. faecium, E. hirae, } \\
\text { Lactobacillus plantarum, L. sakei, Lactococcus } \\
\text { lactis, Bacillus coagulans, B. subtilis, Listeria } \\
\text { innocua, L. monocytogenes, Pediococcus sp. }\end{array}$ \\
\hline & Enterocin P (Cintas et al., 1998) & $4649 \mathrm{Da}$ & $\begin{array}{l}\text { Enterococcus } \\
\text { faecium }\end{array}$ & Lactobacillus sakei, Enterococcus faecium \\
\hline \multirow[t]{4}{*}{$\begin{array}{l}\text { Class II } \\
\text { Subclass IIb }\end{array}$} & $\begin{array}{l}\text { Enterocin I (L50A) (Cintas et al., 1998; } \\
\text { Basanta et al., 2008) }\end{array}$ & $5209 \mathrm{Da}$ & $\begin{array}{l}\text { Enterococcus } \\
\text { faecium }\end{array}$ & $\begin{array}{l}\text { Clostridium sp., Propionibacterium, Listeria } \\
\text { monocytogenes, Lactobacillus sakei, } \\
\text { Enterococcus faecium, Pediococcus acidilactici, } \\
\text { P. pentosaceus }\end{array}$ \\
\hline & Enterocin Q (Basanta et al. 2008) & $\begin{array}{c}3970,31 \\
\mathrm{Da}\end{array}$ & $\begin{array}{l}\text { Enterococcus } \\
\text { faecium }\end{array}$ & Lactobacillus sakei, Enterococcus faecium \\
\hline & Enterocin Xalfa (Hu et al., 2010) & $4420 \mathrm{Da}$ & $\begin{array}{l}\text { Enterococcus } \\
\text { faecium }\end{array}$ & $\begin{array}{l}\text { Enterococcus faecalis, E. faecium, E. hirae, } \\
\text { Lactobacillus plantarum, L. sakei, Lactococcus } \\
\text { lactis, Listeria innocua }\end{array}$ \\
\hline & Enterocin Xbeta (Hu et al., 2010) & $4068 \mathrm{Da}$ & $\begin{array}{l}\text { Enterococcus } \\
\text { faecium }\end{array}$ & $\begin{array}{l}\text { Enterococcus faecalis, E. faecium, E. hirae, } \\
\text { Lactobacillus plantarum, L. sakei, Bacillus } \\
\text { circulans, B. coagulans, B. subtilis, } \\
\text { Listeria innocua }\end{array}$ \\
\hline \multirow[t]{4}{*}{$\begin{array}{l}\text { Class II } \\
\text { Subclass IIc }\end{array}$} & Enterocin B (Casaus et al., 1997) & $5484 \mathrm{Da}$ & $\begin{array}{l}\text { Enterococcus } \\
\text { faecium }\end{array}$ & $\begin{array}{l}\text { Enterococcus faecalis, E. faecium, E. hirae, } \\
\text { Lactobacillus plantarum, L. sakei, Bacillus } \\
\text { coagulans, B. subtilis }\end{array}$ \\
\hline & Hiracin JM79 (Sánchez et al., 2007) & $5093 \mathrm{Da}$ & $\begin{array}{l}\text { Enterococcus } \\
\text { hirae DCH5 }\end{array}$ & $\begin{array}{l}\text { Lactobacillus helveticus, L. curvatus, } \\
\text { L. bulgaricus, L. sakei, Pediococcus pentosaceus, } \\
\text { Enterococcus faecium, E. faecalis, } \\
\text { Propionibacterium acidipropionici, } \\
\text { Clostridium tyrobutyricum, Listeria } \\
\text { monocytogenes, L. ivanovii, L. seeligeri, } \\
\text { L. welshimeri, L. grayi, Staphylococcus aureus }\end{array}$ \\
\hline & Durancin TW-49M (Hu et al., 2008) & $5247 \mathrm{Da}$ & $\begin{array}{l}\text { Enterococcus } \\
\text { durans QU } 49\end{array}$ & $\begin{array}{l}\text { Enterococcus faecalis, E. faecium, E. hirae, } \\
\text { Lactobacillus alimentarius, L. kimchii, } \\
\text { L. plantarum, L. sakei ssp, Lactococcus lactis, } \\
\text { Geobacillus stearothermophilus, Bacillus } \\
\text { subtilis, B. coagulans, B. circulans }\end{array}$ \\
\hline & Enterocin 96 (Izquierdo et al., 2009) & $5494 \mathrm{Da}$ & $\begin{array}{l}\text { Enterococcus } \\
\text { faecalis }\end{array}$ & $\begin{array}{l}\text { Enterococcus faecalis, E. faecium, E. hirae, } \\
\text { E. pseudoavium, E. sulfureus, E. saccharolyticus, } \\
\text { E. columbae, Lactobacillus plantarum, } \\
\text { L. acidophilus, L. sakei, L. paracasei, } \\
\text { Lactococcus lactis, Leuconostoc mesenteroides, } \\
\text { Bacillus subtilis, B. cereus, Listeria innocua, } \\
\text { L. monocytogenes, Staphylococcus xylosus, } \\
\text { S. aureus, Salmonella Typhimurium, Klebsiella } \\
\text { pneumoniae, Serratia liquefaciens, Proteus } \\
\text { vulgaris, Enterobacter cloacae, Escherichia coli }\end{array}$ \\
\hline
\end{tabular}


Table II continued

\begin{tabular}{|l|l|l|l|l|}
\hline $\begin{array}{c}\text { Classes of } \\
\text { bacteriocines }\end{array}$ & \multicolumn{1}{|c|}{ Enterocine } & $\begin{array}{c}\text { Molecular } \\
\text { weight }\end{array}$ & $\begin{array}{c}\text { Producing } \\
\text { strain }\end{array}$ & \multicolumn{1}{c|}{ Activity against bacteria } \\
\hline Class III & Enterolisin A (Nilsen et al., 2003 & $34525 \mathrm{Da}$ & $\begin{array}{l}\text { Enterococcus } \\
\text { faecalis }\end{array}$ & $\begin{array}{l}\text { Lactobacillus sakei, L. brevis, L. curvatus, } \\
\text { Lactococcus cremoris, L. lactis, Pediococcus } \\
\text { pentosaceus, P. acidilactici, Enterococcus } \\
\text { faecium, E. faecalis, Listeria innocua, } \\
\text { L. ivanovii, Bacillus subtilis, B. cereus, } \\
\text { Staphylococcus carnosus, Propionibacterium } \\
\text { ensenii }\end{array}$ \\
\hline Unclassified & $\begin{array}{l}\text { Enterocin AS-48 (Sánchez-Barrena et al., } \\
\text { 2003; Sánchez-Hidalgo et al., 2011) }\end{array}$ & $7187 \mathrm{Da}$ & $\begin{array}{l}\text { Enterococcus } \\
\text { faecalis }\end{array}$ & $\begin{array}{l}\text { Bacillus subtilus, B. cereus, B. circulans, } \\
\text { Corynebacterium glutamicum, C. bovis, } \\
\text { Mycobacterium phlei, Nocardia corrallina, } \\
\text { Micrococcus luteus, M. lysodeikticus, } \\
\text { Staphylococcus aureus, Enterococcus faecalis, } \\
\text { E. faecium, Enterobacter cloacae, Escherichia } \\
\text { coli, Klebsiella pneumoniae, Proteus inconstans, } \\
\text { Salmonella Typhimurium, Shigella sonnei, } \\
\text { Pseudomonas fluorescens, P. aeruginosa }\end{array}$ \\
\hline
\end{tabular}

Table III

Basic characteristics of selected bacteriocins of Gram-negative bacteria

\begin{tabular}{|l|l|l|l|l|}
\hline $\begin{array}{c}\text { Classes of } \\
\text { bacteriocines }\end{array}$ & \multicolumn{1}{|c|}{ Bacteriocine } & $\begin{array}{c}\text { Molecular } \\
\text { weight }\end{array}$ & \multicolumn{1}{|c|}{$\begin{array}{c}\text { Producing strain } \\
\text { Activity against } \\
\text { bacteria }\end{array}$} \\
\hline \multirow{5}{*}{ Colicins } & Colicin B (Schramm et al., 1987; Kolter and Moreno, 1992) & $54863 \mathrm{Da}$ & Escherichia coli & Enterobacteriaceae \\
\cline { 2 - 5 } & Colicin U (Šmajs et al., 1997; Šmarda and Šmajs, 1998) & $66289 \mathrm{Da}$ & Schigella boydii & Enterobacteriaceae \\
\cline { 2 - 5 } & Colicin E2 (Lau et al., 1984; Cole et al., 1985) & $61629 \mathrm{Da}$ & Escherichia coli & Enterobacteriaceae \\
\cline { 2 - 5 } & Colicin E8 (Uchimura and Lau, 1987; Toba et al., 1988) & $23198 \mathrm{Da}$ & Escherichia coli & Enterobacteriaceae \\
\cline { 2 - 5 } & Colicin M (Ölschläger and Braun, 1987) & $29505 \mathrm{Da}$ & Escherichia coli & Enterobacteriaceae \\
\hline \multirow{5}{*}{ Microcins } & Microcin B17 (Baquero and Moreno, 1984; Vizán et al., 1991) & $3274 \mathrm{Da}$ & Escherichia coli & Enterobacteriaceae \\
\cline { 2 - 5 } & Microcin J25 (Salomon and Farias, 1992; Rintoul et al., 2001) & $2144 \mathrm{Da}$ & Escherichia coli & Enterobacteriaceae \\
\cline { 2 - 5 } & Microcin H47 (Rodriguez et al., 1999; Azpiroz et al., 2001) & $4883 \mathrm{Da}$ & Escherichia coli & Enterobacteriaceae \\
\cline { 2 - 5 } & Microcin E492 (Lorenzo and Pugsley, 1984; Lagos et al., 1993) & $7906 \mathrm{Da}$ & Klebsiella pneumoniae & Enterobacteriaceae \\
\hline
\end{tabular}

\section{Mechanisms of bacteriocine action}

Most of bacteriocines exerts a bactericidal effect on sensitive cells. The first contact of bacteriocine with a sensitive cell takes place due to electrostatic interactions between a positively charged, hydrophobic bacteriocine molecule and negatively charged phospholipids in cytoplasmic membrane of a sensitive cell (Chen et al., 1997). The mechanism of bacteriocines action involves formation in the cytoplasmic membrane of sensitive bacteria of transient pore and ion channel complexes. This is accompanied by a passive outflow of small molecules, such as potassium, magnesium and phosphorus ions, amino acids and ATP. This causes a disturbance in membrane potential, $\mathrm{pH}$ gradient and function of the proton pump becomes inhibited. The low level of ATP and ion deficit in the cell results in inhibition of DNA, RNA, protein and polysaccharide synthesis, and finally leads to death of the bacterial cell (Moll et al., 1999;
Rodriguez et al., 2002). Such mechanism was described for L. monocytogenes under effect of sakacine P, produced by Lactobacillus sakei subsp. sakei 2a, or pediocin PA-1, produced by Pediococcus acidilactici (Rodriguez et al., 2002; de Carvalho et al., 2010).

Another mechanism of bacteriocines activity involves their ability to induce lysis of bacterial cells. The process is linked to interaction of bacteriocines with teicholic, lipoteicholic and teichuronic acids, representing coponents of cell wall. This results in a release and activation of autolytic enzymes, linked to the cell, which results in cell autolysis. Such activity was described for plantaricine C produced by L. plantarum LL441 and bacteriocines produced by L. delbrueckii subsp. bulgaricus LMG 13551 strain (Gonzáles et al., 1994). Bacteriocines belonging to lantibiotics class may additionally interrupt processes of cell wall biosynthesis. They inhibit synthesis of peptidoglycan at the transglycosylation stage, which is not accompoanied by a disturbed biosynthesis of DNA, 
RNA or protein (Moll et al., 1999). The lantibiotics inhibiting peptidoglycan synthesis include mersacidin that inhibits peptidoglycan synthesis through a specific interaction with the peptidoglycan precursor lipid II. The sequestering of lipid II prevents its utilization by the transpeptidase and transglycosylase enzymes that install the crosslinked network of the bacterial cell wall. Mersacidin appears to bind to a different portion of lipid II than does vancomycin, indicating that this bacteriocin may prove to have important chemotherapeutic applications (Brotz et al., 1995; Brotz et al., 1997).

Mechanism of cell-targeted activity manifested by bacteriocines produced by Gram-negative bacteria include depolarization of cell membranes (e.g., colicin E1), damage to DNA (e.g., colicin E2, acting as a non-specific endonuclease) or inhibition of protein synthesis by inactivation of ribosomal RNA (colicin E3 and cloacin DF13). Colicin E1 is coded by a set of genes representing 'colicin casette' in ColE1 plasmid. As mentioned above, the produced colicin is lethal for the host since its release to the environment results in cell lysis, for which product of kil gene is responsible. In normal conditions the entire system is located on a plasmid in a repressed condition, which results from blocking of the principal promoter (Pcol) by the repressor - cellular protein of LexA. Cells which at a given moment do not produce colicin even if they contain the ColE1 plasmid, are protected from action of exogenous colicin due to function of imm gene product while the related bacteria containing no such plasmid become eliminated from the environment. All situations resulting in destruction of the LexA protein, and, thus, inducing the cellular SOS system mobilize in paralel colicin production by the entire population of bacteria carrying the plasmid (Riley and Gordon, 1999; Włodarczyk, 2002; Cascales et al., 2007).

Bacteriocines, as molecules of low molecular weight and usually a hydrophobic character, tend to form aggregates, which reduces their activity (Karpiński, 2012). The example includes propionicin (PLG-1), which a small molecule of around $10 \mathrm{kDa}$ and forms aggregates of molecular weight above $100 \mathrm{kDa}$ (Lyon and Glatz, 1993). On the other hand, lactacin B tend to form macromolecular complexes with lipid and carbohydrate components of culture media (Barefoot and Klaenhammer, 1984). Activity of bacteriocines may be increased by destruction of the aggregates and an increase in numer of active molecules using mild detergent such as Triton X100. For example, antibacterial activity of cerein 7 increases after TritonX100 tratment, most probably due to desaggregation of larger molecules (Oscáriz and Pisabarro 2000). The ability to disintegrate bacteriocine aggregates was also shown for urea, which, induces a 200-fold increase in activity of lactacin B (Barefoot and Klaenhammer, 1984).

\section{Application of bacteriocines}

At present, studies continue on application of bacteriocines in food industry and in medicine. Until now, exclusively nisine was commonly used in food industry, as a conserving agent (Schillinger et al., 1999).

Nisin and other lanibiotics have been investigated for their potential applications in medicine. The MICs of nisin A and mutacin B-Ny266 were shown to be comparable to those of vancomycin and oxacillin against various bacterial pathogens (Mota-Meira et al., 2000). Both lantibiotics were active against vancomycin- and oxacillin-resistant strains of $H$. pylori and Neisseria spp. This opens the potential of using lantibiotics in treatment of infections induced by the above mentioned bacteria (Hancock, 1997; Mota-Meira et al., 2000). Clinical action of mersacidin was also demonstrated. Mersacidin has been shown to be very effective for the treatment of systemic staphylococcal infections, and in eliminating nasal carriage of S. aureus in a mouse rhinitis model (Chatterjee et al., 1992; Kruszewska et al., 2004). Unfortunately, it was also found that S. aureus strains can develop and maintain resistance against nisin A in vitro. This suggests that resistance to nisin A and other lantibiotics with similar modes of action would arise in the clinic if these agents are used as chemotherapeutic drugs (Blake et al., 2011). Recent studies showed that new bacteriocins - enterocin RM6, produced by E. faecalis, and bacteriocin KU24 produced by L. lactis KU24, are also active against S. aureus, including methicillin-resistant $S$. aureus (MRSA) (Huang et al., 2013; Lee et al., 2013).

Another bacteriocine - cinnamycin, shows an inhibitory effect on phospholipase A2, the enzyme active in synthesis of prostaglandins and leukotrienes in the human immune system. Its action takes place by the sequestration of its substrate phosphatidylethanolamine. Due to this activity, cinnamycin may prove to have a useful application as an anti-inflammatory and anti-allergy drug (Marki et al., 1991).

Bacteria of the Lactobacillus genus are frequently employed in probiotic preparations. The main duty of probiotic bacteria involves maintenance of microbiological equilibrium in alimentary tract through interactions with pathogenic bacteria (Słońska and Klimuszko, 2010; Klewicka et al., 2011). In addition, probiotic preparations manifest an anti-noeplastic activity (Burns and Rowland, 2000; Sand et al., 2007). Moreover, lactic acid bacteria and the produced by them bacteriocines are applied in production of cheeses, yoghurts and other dairy products (Garde et al., 1997; Beshkova and Frengova, 2012). In 2012 one of the S. salivarius 24SMB strains, deposited as DSM 23307, was selected as a new potential oral probiotic, thanks to its safety assessment, ability to inhibit Streptococcus pneumoniae 
and the absence of virulence and antibiotic resistance genes (Santagati et al., 2012).

Bacteriocines produced by Gram-negative bacteria find application in poultry and cattle breeding. Microcines produced by various E. coli strains play a significant role in preventing chicken infections with Salmonella since microcins are capable of inhibiting growth of pathogenic Salmonella strains (Portrait et al., 1999). Colicins and microcins are also used against E. coli $\mathrm{O} 157: \mathrm{H} 7$. Microcins and colicins manifest their activity against strains producing shiga toxin, and also against other E. coli strains of serotype O. The use of colicin- and microcin-producing bacteria as probiotics may markedly reduce pathogens level in cattle alimentary tract and in this way prevent against infection with pathogenic strains (Walterspiel et al., 1992).

The bacteriocin from Pediococcus acidilactici K2a2-3 were found to be cytotoxic against human colon adenocarcinoma (HT29) and human cervical carcinoma (HeLa) cells in vitro, as determined by MTT assay. Cytotoxicity may be due in part to the high level of hydrophobicity of this bacteriocin (Villarante et al., 2011). Whereas, nisin may serve as a potential therapeutic for treating head and neck squamous cell carcinoma. Nisin induces preferential apoptosis, cell cycle arrest, and reduces cell proliferation in squamous carcinoma cells (Joo et al., 2012).

Some of bacteriocines may exert a toxic effect and may influence course of infections. Cytolysine produced by strains of E. faecalis and E. faecium manifest a cytolytic activity inducing $\beta$-haemolysis of rabbit, horse and human erythrocytes and, smetimes, of sheep erythrocytes (Archimbaud et al., 2002; Coburn et al., 2004). Moreover, studies on the course of E. faecalis - induced infections in rabbits and mice, demonstrated that strains which produced cytolysine evoked infections of a more severe course and resulting in higher mortality than infections with strains free of this trait (Chow et al., 1993; Dupton et al., 1998).

In various scientific centres studies continue on bacteriocinogenic strains and the produced by them bacteriocines and on clinical trials of their application. The antibacterial activity of bacteriocines, similarly to that of other substances (silver and gold nanoparticles, plant-derivered products, bacteriophage lytic enzymes) open perspective for their use in medicine (Kurek et al., 2011; Wolska et al., 2012). This is particularly important due to the increasing antibiotic resistance of pathogenic bacterial species.

\section{Summary}

Bacteriocines, as peptides of antibacterial properties, manifest high significance for preservation of homeostasis between bacteria. They help humans in preservation of health, they find application in food industry and in medicine. Bacteriocines produced by lactic acid bacteria have been recognized to be fully safe for humans. At present, bacteriocines and probiotic preparations provide an alternative for antibiotics, used as a supplementation of fodder. However, a broader application of bacteriocines requires further studies on their structure, mechanisms of action and their new potential applications.

\section{Literature}

Allison G.E., C. Fremaux and T.R. Klaenhammer. 1994. Expansion of bacteriocin activity and host range upon complementation of two peptides encoded within the lactacin F operon. J. Bacteriol. 176: 2235-2241.

Andrzejewska E. and A. Szkaradkiewicz. 2007. Evaluation of the antagonistic effect of Lactobacillus acidophilus on clinical strains of Helicobacter pylori (in Polish). Med. Dośw. 59: 59-64.

Andrzejewska E. and A.K. Szkaradkiewicz. 2012. Antagonistic effect of Lactobacillus acidophilus to selected periodontopathogens (in Polish). XXVII Congress of the Polish Society of Microbiologists. September 5-8, 2012, Lublin, Poland. Abstracts: P-X-381.

Archimbaud C., N. Shankar, C. Forestier, A. Baghdayan, M.S. Gilmore, F. Charbonné and B. Joly. 2002. In vitro adhesive properties and virulence factors of Enterococcus faecalis strains. Res. Microbiol. 153: 75-80.

Aymerich T., H. Holo, L.S. Håvarstein, M. Hugas, M. Garriga and I.F. Nes. 1996. Biochemical and genetic characterization of enterocin A from Enterococcus faecium, a new antilisterial bacteriocin in the pediocin family of bacteriocins. Appl. Environ. Microbiol. 62: 1676-1682.

Azpiroz M.F., E. Rodriguez and M. Lavina. 2001. The structure, function, and origin of the microcin H47 ATP-binding cassette exporter indicate its relatedness to that of colicin V. Antimicrob. Agents Chemother. 45: 969-972.

Bactibase. 2013. Database dedicated to bacteriocins. http://bactibase.pfba-lab-tun.org/main.php.

Bagel. 2013. Bagel automated bacteriocin mining. http://bagel2. molgenrug.nl

Baquero F. and F. Moreno. 1984. The microcins. FEMS Microbiol. Lett. 23(2-3): 117-124.

Barefoot S.F. and T.R. Klaenhammer. 1984. Purification and characterization of the Lactobacillus acidophilus bacteriocin lactacin B. Antimicrob. Agents Chemother. 26: 328-334.

Basanta A., J. Sánchez, B. Gómez-Sala, C. Herranz, P.E. Hernández and L.M. Cintas. 2008. Antimicrobial activity of Enterococcus faecium L50, a strain producing enterocin L50 (L50A and L50B), $\mathrm{P}$ and $\mathrm{Q}$, against beer-spoilage lactic acid bacteria in broth, wort (hopped and unhopped), and alcoholic and non-alcoholic lager beers. Int. J. Food Microbiol. 125: 293-307.

Beshkova D. and G. Frengova. 2012. Bacteriocins from lactic acid bacteria: microorganisms of potential biotechnological importance for the diary industry. Eng. Life Sci. 12: 1-14.

Birri D.J., D.A. Brede, T. Forberg, H. Holo and I.F. Nes. 2010. Molecular and genetic characterization of a novel bacteriocin locus in Enterococcus avium isolates from infants. Appl. Environ. Microbiol. 76: 483-492.

Blake K.L., C.P. Randall and A.J. O'Neill. 2011. In vitro studies indicate a high resistance potential for the lantibiotic nisin in Staphylococcus aureus and define a genetic basis for nisin resistance. Antimicrob. Agents Chemother. 55: 2362-2368. 
Braun V., S.I. Patzer and K. Hantke. 2002. Ton-dependent colicins and microcins: modular design and evolution. Biochimie. 84: 365-380.

Brotz H., G. Bierbaum, A. Markus, E. Molitor and H.G. Sahl. 1995. Mode of action of the lantibiotic mersacidin: inhibition of peptidoglycan biosynthesis via a novel mechanism? Antimicrob. Agents Chemother. 39: 714-719.

Brotz H., G. Bierbaum, P.E. Reynolds and H.G. Sahl. 1997. The lantibiotic mersacidin inhibits peptidoglycan biosynthesis at the level of transglycosylation. Eur. J. Biochem. 246: 193-199.

Burns A.J. and I.R. Rowland. 2000. Anti-carcinogenicity of probiotics and prebiotics. Curr. Issues Intest. Microbiol. 1: 13-24.

Casaus P., T. Nilsen, L.M. Cintas, I.F. Nes, P.E. Hernández and H. Holo. 1997. Enterocin B, a new bacteriocin from Enterococcus faecium T136 which can act synergistically with enterocin A. Microbiology 143 : 2287-2294.

Cascales E., S.K. Buchanan, D. Duché, C. Kleanthous, R. Lloubes, K. Postle, M. Riley, S. Slatin and D. Cavard. 2007. Colicin biology. Microbiol. Mol. Biol. Rev. 71: 158-229.

Chatterjee S., S. Chatterjee, S.J. Lad, M.S. Phansalkar, R.H. Rupp, B.N. Ganguli, H.W. Fehlhaber and H. Kogler. 1992. Mersacidin, a new antibiotic from Bacillus. Fermentation, isolation, purification and chemical characterization. J. Antibiot. (Tokyo) 45: 832-838.

Cheigh C.-I. and Y.-R. Pyun. 2005. Nisin biosynthesis and its properties. Biotechnol. Lett. 27: 1641-1648.

Chen Y., R. Shapira, M. Eisenstein and T.J. Montville. 1997. Functional characterization of pediocin PA-1 binding to liposomes in the absence of a protein receptor and its relationship to a predicted tertiary structure. Appl. Environ. Microbiol. 63: 524-531.

Chow J.W., L.A. Thal, M.B. Perri, J.A. Vazquez, S.M. Donabedian, D.B. Clewell and M.J. Zervos. 1993. Plasmid-associated hemolysin and aggregation substance production contribute to virulence in experimental enterococcal endocarditis. Antimicrob. Agents Chemother. 37: 2474-2477.

Cintas L.M., P. Casaus, C. Herranz, L.S. Havarstein, H. Holo, P.E. Hernandez and I.F. Nes. 2000. Biochemical and genetic evidence that Enterococcus faecium L50 produces enterocins L50A and L50B, the sec-dependent enterocin P, and a novel bacteriocin secreted without an $\mathrm{N}$-terminal extension termed enterocin $\mathrm{Q}$. J. Bacteriol. 182: 6806-6814.

Cintas L.M., P. Casaus, M.F. Fernández and P.E. Hernández. 1998; Comparative antimicrobial activity of enterocin L50, pediocin PA01, nisin A and lactocin S against spoilage and foodborne pathogenic bacteria. Food Microbiol. 15: 289-298.

Clewell D.B. 1990. Movable genetic elements and antibiotic resistance in enterococci. Eur. J. Clin. Microbiol. Infect. Dis. 9: 90-102. Coburn P.S. and M.S. Gilmore. 2003. The Enterococcus faecalis cytolysin: a novel toxin active against eukaryotic and prokaryotic cells. Cell Microbiol. 5: 661-669.

Coburn P.S., C.M. Pillar, B.D. Jett, W. Haas and M.S. Gilmore. 2004. Enterococcus faecalis senses target cells and in response expresses cytolysin. Science 306: 2270-2272.

Coconnier M.-H., V. Lievin, E. Hemery and A.L. Servin. 1998. Antagonistic activity against Helicobacter infection in vitro and in vivo by the human Lactobacillus acidophilus strain LB. Appl. Environ. Microbiol. 64: 4573-4580.

Cole S.T., B. Saint-Joanis and A.P. Pugsley. 1985. Molecular characterisation of the colicin E2 operon and identification of its products. Mol. Gen Genet. 198: 465-472.

Contreras B.G., L. De Vuyst, B. Devreese, K. Busanyova, J. Raymaeckers, F. Bosman, E. Sablon and E.J. Vandamme. 1997. Isolation, purification, and amino acid sequence of lactobin A, one of the two bacteriocins produced by Lactobacillus amylovorus LMG P-13139. Appl. Environ. Microbiol. 63: 13-20.
Cox C.R., P.S. Coburn and M.S. Gilmore. 2005. Enterococcal cytolysin: a novel two component peptide system that serves as a bacterial defense against eukaryotic and prokaryotic cells. Curr. Protein Pept. Sci. 6: 77-84.

Cuozzo S.A., F. Sesma, J.M. Palacios, A.P. de Ruiz Holgado and R.R. Raya. 2000. Identification and nucleotide sequence of genes involved in the synthesis of lactocin 705, a two-peptide bacteriocin from Lactobacillus casei CRL 705. FEMS Microbiol. Lett. 185: 157-161.

de Carvalho K.G., F.H.S. Bambirra, M.F. Kruger, M.S. Barbosa, J.S. Oliveira, A.M.C. Santos, J.R. Nicoli, M.P. Bemquerer, A. de Miranda, E.J. Salvucci, F.J.M. Sesma and B.D.G.M. Franco. 2010. Antimicrobial compounds produced by Lactobacillus sakei subsp. sakei 2a, a bacteriocinogenic strain isolated from a Brazilian meat product. J. Ind. Microbiol. Biotechnol. 37: 381-390.

de Lorenzo V. and A.P. Pugsley. 1985. Microcin E492, a lowmolecular-weight peptide antibiotic which causes depolarization of the Escherichia coli cytoplasmic membrane. Antimicrob Agents Chemother. 27: 666-669.

De Vuyst L., L. Avonts, P. Neysens, B. Hoste, M. Vancanneyt, J. Swings and R. Callewaert. 2004. The lactobin A and amylovorin L471 encoding genes are identical, and their distribution seems to be restricted to the species Lactobacillus amylovorus that is of interest for cereal fermentations. Int. J. Food Microbiol. 90: 93-106.

Delves-Broughton J., P. Blackburn, R.J. Evans and J. Hugenholtz. 1996. Applications of the bacteriocin, nisin. Antonie van Leeuwenhoek 69: 193-202.

Diep D.B., L.S. Håvarstein and I.F. Nes. 1995. A bacteriocin-like peptide induces bacteriocin synthesis in Lactobacillus plantarum C11. Mol. Microbiol. 18: 631-639.

Dupton H., P. Montravers, J. Mohler and C. Carbon. 1998. Disparate findings on the role of virulence factors of Enterococcus faecalis in mouse and rat model. Infect. Immun. 66: 2570-2575.

Feng G., G.K.P. Guron, J.J. Churey and R.W. Worobo. 2009. Characterization of mundticin L, a class IIa anti-Listeria bacteriocin from Enterococcus mundtii CUGF08. Appl. Environ. Microbiol. 75: 5708-5713.

Ferchichi M., J. Frère, K. Mabrouk and M. Manai. 2001. Lactococcin MMFII, a novel class IIa bacteriocin produced by Lactococcus lactis MMFII, isolated from a Tunisian dairy product. FEMS Microbiol. Lett. 205: 49-55.

Ferchichi M., M. Fathallah, P. Mansuelle, H. Rochat, J.M. Sabatier, M. Manai and K. Mabrouk. 2001. Chemical synthesis, molecular modeling, and antimicrobial activity of a novel bacteriocin, MMFII. Biochem. Biophys. Res. Commun. 289: 13-18.

Flynn S., D. van Sinderen, G.M. Thornton, H. Holo, I.F. Nes and J.K. Collins. 2002. Characterization of the genetic locus responsible for the production of ABP-118, a novel bacteriocin produced by the probiotic bacterium Lactobacillus salivarius subsp. salivarius UCC118. Microbiol. 148: 973-984.

Franz C.M.A.P., M.J. van Belkum, W.H. Holzapfel, H. Abriouel and A. Gálvez. 2007. Diversity of enterococcal bacteriocins and their grouping in a new classification scheme. FEMS Microbiol. Rev. 31: 293-310.

Fremaux C., Y. Héchard and Y. Cenatiempo. 1995. Mesentericin Y105 gene clusters in Leuconostoc mesenteroides Y105. Microbiology 141: 1637-1645.

Fuller R. 1989. Probiotics in man and animals. J. Appl. Bacteriol. 66: 365-378.

Gálvez A., E. Valdivia, H. Abriouel, E. Camafeita, E. Mendez, M. Martinez-Bueno and M. Maqueda. 1998. Isolation and characterization of enterocin EJ97, a bacteriocin produced by Enterococcus faecalis EJ97. Arch. Microbiol. 171: 59-65.

Garde S., P. Gaya, M. Medina and M. Nunez. 1997. Acceleration of flavour formation in cheese by a bacteriocin-producing adjunct lactic culture. Biotechnol Lett. 10: 1011-1014. 
Garneau S., N.I. Martin and J.C. Vederas. 2002. Two-peptide bacteriocins produced by lactic acid bacteria. Biochimie 84: 577-592. González B., P. Arca, B. Mayo and J.E. Suárez. 1994. Detection, purification, and partial characterization of plantaricin $\mathrm{C}$, a bacteriocin produced by a Lactobacillus plantarum strain of diary origin. Appl. Environ. Microbiol. 60: 2158-2163.

Gwiazdowska D. and K. Trojanowska. 2005. Bacteriocins - properties and antimicrobial activity (in Polish). Biotechnologia 1: 114-130. Hancock R.E.W. 1997. Peptide antibiotics. Lancet 349: 418-422. Hastings J.W., M. Sailer, K. Johnson, K.L. Roy, J.C. Vederas and M.E. Stiles. 1991. Characterization of leucocin A-UAL 187 and cloning of the bacteriocin gene from Leuconostoc gelidum. J. Bacteriol. 173: 7491-7500.

Héchard Y., B. Dérijard, F. Letellier and Y. Cenatiempo. 1992. Characterization and purification of mesentericin Y105, an antiListeria bacteriocin from Leuconostoc mesenteroides. J. Gen. Microbiol. 138(12): 2725-2731.

Heng N.C., G.A. Burtenshaw, R.W. Jack and J.R. Tagg. 2007. Ubericin A, a class IIa bacteriocin produced by Streptococcus uberis. Appl. Environ. Microbiol. 73: 7763-7766.

Hetz C., M.R. Bono, L.F. Barros and R. Lagos. 2002. Microcin E 492, a channel-forming bacteriocin from Klebsiella pneumoniae, induces apoptosis in some human cell lines. Proc. Natl. Acad. Sci. USA 99: 2696-2701.

Holck A.L., L. Axelsson and U. Schillinger. 1994. Purification and cloning of piscicolin 61, a bacteriocin from Carnobacterium piscicola LV61. Curr. Microbiol. 29: 63-68.

Hu C.B., T. Zendo, J. Nakayama and K. Sonomoto. 2008. Description of durancin TW-49M, a novel enterocin B-homologous bacteriocin in carrot-isolated Enterococcus durans QU 49. J. Appl. Microbiol. 105: 681-690.

Hu C.B., W. Malaphan, T. Zendo, J. Nakayama and K. Sonomoto. 2010. Enterocin X, a novel two-peptide bacteriocin from Enterococcus faecium KU-B5, has an antibacterial spectrum entirely different from those of its component peptides. Appl. Environ. Microbiol. 76: 4542-4545.

Huang E., Z. Liwen, Y.-K. Chung, Z. Zheng and A.E. Yousef. 2013. Characterization and application of enterocin RM6, a bacteriocin from Enterococcus faecalis. BioMed. Res. Int. 2013, Article ID 206917.

I-TASSER. 2012. Server for protein structure and function prediction. http://zhanglab.ccmb.med.umich.edu/I-TASSER/

Izquierdo E., C. Wagner, E. Marchioni, D. Aoude-Werner and S. Ennahar. 2009. Enterocin 96, a novel class II bacteriocin produced by Enterococcus faecalis WHE 96, isolated from Munster cheese. Appl. Environ. Microbiol. 75: 4273-4276.

Jack R.W., J.R. Tagg and B. Ray. 1995. Bacteriocins of Gram-positive bacteria. Microbiol. Rev. 59: 171-200.

Joerger M.C. and T.R. Klaenhammer. 1986. Characterization and purification of helveticin J and evidence for a chromosomally determined bacteriocin produced by Lactobacillus helveticus 481 . J. Bacteriol. 167: 439-446.

Joo N.E., K. Ritchie, P. Kamarajan, D. Miao and Y.L. Kapila. 2012. Nisin, an apoptogenic bacteriocin and food preservative, attenuates HNSCC tumorigenesis via CHAC1. Cancer Med. 1: 295-305.

Karpiński T.M. 2012. New peptide (Entap) with anti-proliferative activity produced by bacteria of Enterococcus genus (in Polish). Habilitation thesis. Wydawnictwo Naukowe Uniwersytetu Medycznego im. Karola Marcinkowskiego w Poznaniu. pp. 102.

Klaenhammer T.R. 1993. Genetics of bacteriocins produced by lactic acid bacteria. FEMS Microbiol. Rev. 12: 39-86.

Klewicka E., B. Cukrowska, Z. Libudzisz, K. Slizewska and I. Motyl. 2011. Changes in gut microbiota in children with atopic dermatitis administered the bacteria Lactobacillus casei DN-114001. Pol. J. Microbiol. 60: 329-333.
Kolter R. and F. Moreno. 1992. Genetics of ribosomally synthesized peptide antibiotics. Annu. Rev. Microbiol. 46: 141-163.

Kruszewska D., H.G. Sahl, G. Bierbaum, U. Pag, S.O. Hynes and A. Ljungh. 2004. Mersacidin eradicates methicillin-resistant Staphylococcus aureus (MRSA) in a mouse rhinitis model. J. Antimicrob. Chemother. 54: 648-653.

Kurek A., A.M. Grudniak, A. Kraczkiewicz-Dowjat and K.I. Wolska. 2011. New antibacterial therapeutics and strategies. Pol. J. Microbiol. 60: 3-12.

Lagos R., M. Wilkens, C. Vergara, X. Cecchi and O. Monasterio. 1993. Microcin E492 forms ion channels in phospholipid bilayer membrane. FEBS Lett. 321: 145-148.

Lau P.C.K., R.W. Rowsome, M. Zuker and L.P. Visentin. 1984. Comparative nucleotide sequences encoding the immunity proteins and the carboxyl-terminal peptides of colicins E2 and E3. Nucleic Acids Res. 12: 8733-8745.

Lee N.-K., E.J. Han, K.J. Han, and H.-D. Paik. 2013. Antimicrobial effect of bacteriocin KU24 produced by Lactococcus lactis KU24 against methicillin-resistant Staphylococcus aureus. J. Food Sci. 78: M465-M469.

Leer R.J., J.M.B.M. van der Vossen, M. van Giezen, J.M. van Noort and P.H. Pouwels. 1995. Genetic analysis of acidocin B, a novel bacteriocin produced by Lactobacillus acidophilus. Microbiol. 141: 1629-1635.

Libudzisz Z. 2002. Microbiological and technological aspects of probiotics (in Polish). In: Probiotics. Wyd. Nauk. PTTŻ, Kraków. pp. 11-22.

Lozano J.C.N., J.N. Meyer, K. Sletten, C. Peláz and I.F. Nes. 1992. Purification and amino acid sequence of a bacteriocin produced by Pediococcus acidilactici. J. Gen. Microbiol. 138: 1985-1990.

Lyon W.J. and B.A. Glatz. 1993. Isolation and purification of propionicin PLG-1, a bacteriocin produced by a strain of Propionibacterium thoenii. Appl. Environ. Microbiol. 59: 83-88.

Marciset O., M.C. Jeronimus-Stratingh, B. Mollet and B. Poolman. 1997. Thermophilin 13, a nontypical antilisterial poration complex bacteriocin, that functions without a receptor. J. Biol. Chem. 272: 14277-14284.

Marki F., E. Hanni, A. Fredenhagen and J. Oostrum. 1991. Mode of action of the lanthionine-containing peptide antibiotics duramycin, duramycin $\mathrm{B}$ and $\mathrm{C}$, and cinnamycin as indirect inhibitors of phospholipase A2. Biochem. Pharmacol. 42: 2027-2035.

McAuliffe O., R.P. Ross and C. Hill. 2001. Lantibiotics: structure, biosynthesis and mode of action. FEMS Microbiol. Rev. 25: 285-308. Moll G.N., W.N. Konings and A.J.M. Driessen. 1999. Bacteriocins: mechanism of membrane insertion and pore formation. Antonie van Leeuwenhoek 76: 185-198.

Mota-Meira M., C. Lacroix, G. LaPointe and M.C. Lavoie. 1997. Purification and structure of mutacin B-Ny266: a new lantibiotic produced by Streptococcus mutans. FEBS Lett. 410: 275-279.

Mota-Meira M., G. LaPointe, C. Lacroix and M.C. Lavoie. 2000. MICs of mutacin B-Ny266, nisin A, vancomycin, and oxacillin against bacterial pathogens. Antimicrob. Agents Chemother. 44: 24-29. Mulders J.W., I.J. Boerrigter, H.S. Rollema, R.J. Siezen and W.M. de Vos. 1991. Identification and characterization of the lantibiotic nisin Z, a natural nisin variant. Eur. J. Biochem. 201: 581-584. Nes I.F., D.B. Diep and H. Holo. 2007. Bacteriocin diversity in Streptococcus and Enterococcus. J. Bacteriol. 189: 1189-1198.

Nilsen T., F.N. Ingolf and H. Holo. 2003. Enterolysin A, a cell walldegrading bacteriocin from Enterococcus faecalis LMG 2333. Appl. Environ. Microbiol. 69: 2975-2984.

Nishie M., J. Nagao and K. Sonomoto. 2012. Antibacterial peptides "bacteriocins": an overview of their diverse characteristics and applications. Biocontrol Sci. 17: 1-16.

Nissen-Meyer J., H. Holo, L.S. Håvarstein, K. Sletten and I.F. Nes. 1992. A novel lactococcal bacteriocin whose activity depends on the 
complementary action of two peptides. J. Bacteriol. 174: 5686-5692. Nissen-Meyer J., P. Rogne, C. Oppegård, H.S. Haugen and P.E. Kristiansen. 2009. Structure-function relationships of the nonlanthionine-containing peptide (class II) bacteriocins produced by Gram-positive bacteria. Curr. Pharm. Biotechnol. 10: 19-37.

Olschläger T. and V. Braun. 1987. Sequence, expression, and localization of the immunity protein for colicin M. J. Bacteriol. 169: 4765-4769.

Oppergård C., P. Rogne, L. Emanuelsen, P.E. Kristiansen, G. Fimland and J. Nissen-Meyer. 2007. The two-peptide class II bacteriocins: structure, production, and mode of action. J. Mol. Microbiol. Biotechnol. 13: 210-219.

Oscáriz J.C. and A.G. Pisabarro. 2000. Characterization and mechanism of action of cerein 7, a bacteriocin produced by Bacillus cereus Bc7. J. Appl. Microbiol. 89: 361-369.

Pathmakanthan S., S. Meance and C.A. Edwards. 2000. Probiotics: A review of human studies to date and methodological approaches. Microb. Ecol. Health Dis. 12(suppl. 2): 10-30.

Piard J.C. and M. Desmazeaud. 1992. Inhibiting factors produced by lactic acid bacteria. 2 . Bacteriocins and other antibacterial substances. Lait. 72: 113-142.

Pons A.M., I. Lanneluc, G. Cottencau and S. Sable. 2002. New developments in non-post translationally modified microcins. Biochimie. 84: 531-537.

Portrait V., S. Gendron-Gaillard, G. Cottenceau and AM. Pons. 1999. Inhibition of pathogenic Salmonella enteritidis growth mediated by Escherichia coli microcin J25 producing strains. Can. J. Microbiol. 45: 168-175.

Pridmore R.D., B. Berger, F. Desiere, D. Vilanova, C. Barretto, A.C. Pittet, M.C. Zwahlen, M. Rouvet, E. Altermann, R. Barrangou, B. Mollet, A. Mercenier, T. Klaenhammer, F. Arigoni and M.A. Schell. 2004. The genome sequence of the probiotic intestinal bacterium Lactobacillus johnsonii NCC 533. Proc. Natl. Acad. Sci. USA 101: 2512-2517.

Rafter J. 1995. The role of lactic acid bacteria in colon cancer prevention. Scand. J. Gastroenterol. 30: 497-502.

Riley M.A. and D.M. Gordon. 1999. The ecological role of bacteriocins in bacterial competition. Trends Microbiol. 7: 129-133.

Rintoul M.R., B.F. de Arcuri, R.A. Salomon, R.N. Farias and R.D. Morero. 2001. The antibacterial action of microcin J25: evidence for disruption of cytoplasmic membrane energization in Salmonella newport. FEMS Microbiol. Lett. 204: 265-270.

Rodríguez E., C. Gaggero and M. Lavina. 1999. The structural gene for microcin $\mathrm{H} 47$ encodes a peptide precursor with antibiotic activity. Antimicrob. Agents Chemother. 43: 2176-2182.

Rodriguez J.M., M.I. Martinez and J. Kok. 2002. Pediocin PA-1, a wide-spectrum bacteriocin from lactic acid bacteria. Crit. Rev. Food Sci. Nutr. 42: 91-121.

Rolfe R.D. 2000. The role of probiotic cultures in the control of gastrointestinal health. J. Nutr. 130: 396S-402S.

Ross K.F., C.W. Ronson and J.R. 1993. Tagg. Isolation and characterization of the lantibiotic salivaricin A and its structural gene salA from Streptococcus salivarius 20P3. Appl. Environ. Microbiol. 59: 2014-2021.

Salminen S., A.C. Ouwehand and E. Isolauri. 1998. Clinical application of probiotic bacteria. Int. Dairy J. 8: 563-572.

Salomón R.A. and R.N. Farías. 1992. Microcin 25, a novel antimicrobial peptide produced by Escherichia coli. J. Bacteriol. 174: 7428-7435.

Sánchez J., D.B. Diep, C. Herranz, I.F. Nes, L.M. Cintas and P.E. Hernández. 2007. Amino acid and nucleotide sequence, adjacent genes, and heterologous expression of hirancin JM79, a sec-dependent bacteriocin produced by Enterococcus hirae DCH5, isolated from Mallard ducks (Anas platyrhynchos). FEMS Microbiol. Lett. 270: 227-236.
Sánchez-Barrena M.J., M. Martínez-Ripoll, A. Gálvez, E. Valdivia, M. Maqueda, V. Cruz and A. Albert. 2003. Structure of bacteriocin AS-48: from soluble state to membrane bound state. J. Mol. Biol. 334: 541-549.

Sánchez-Hidalgo M., M. Montalbán-López, R. Cebrián, E. Valdivia, M. Martínez-Bueno and M. Maqueda. 2011. AS-48 bacteriocin: close to perfection. Cell Mol. Life Sci. 68: 2845-2857.

Sand S.L., T.M. Haug, J. Nissen-Meyer and O. Sand. 2007. The bacterial peptide pheromone plantaricin A permeabilizes cancerous, but not normal, rat pituitary cells and differentiates between the outer and inner membrane leaflet. J. Membr. Biol. 216: 61-71.

Sanders M.E. 2000. Consideration for use of probiotic bacteria to modulate human health. J. Nutr. 130: 384S-390S.

Santagati M., M. Scillato, F. Patanè, C. Aiello and S. Stefani. 2012. Bacteriocin-producing oral streptococci and inhibition of respiratory pathogens. FEMS Immunol. Med. Microbiol. 65: 23-31.

Schillinger U., R. Geigen and W.H. Holzapfel. 1996. Potential of antagonistic microorganisms and bacteriocins for the biological preservation of foods. Trends Food Sci. Technol. 7: 158-164.

Schramm E., J. Mende, V. Braun and R.M. Kamp. 1987. Nucleotide sequence of the colicin B activity gene cba: consensus pentapeptide among TonB-dependent colicins and receptors. J. Bacteriol. 169: 3350-3357.

Shelburne C.E., F.Y. An, V. Dholpe, A. Ramamoorthy, D.E. Lopatin and M.S. Lantz. 2007. The spectrum of antimicrobial activity of the bacteriocin subtilosin A. J. Antimicrob. Chemother. 59: 297-300. Słońska A. and D. Klimuszko. 2010. Bacteriocins of probiotic rods of the Lactobacillus genus (in Polish). Post. Mikrobiol. 40: 87-96.

Šmajs D., H. Pilsl and V. Braun. 1997. Colicin U, a novel colicin produced by Shigella boydii. J. Bacteriol. 179: 4919-4928.

Šmarda J. and D. Šmajs. 1998. Colicins - exocellular lethal proteins of Escherichia coli. Folia Microbiol. 43: 563-582.

Steinka I. 2009. Technology innovations as a factor of food safety (in Polish). Ann. Acad. Med. Gedan. 39: 123-132.

Szkaradkiewicz A.K. and J. Stopa. 2008. Lactobacillus spp. of oral cavity microflora in chronic periodontitis. Pol. J. Environ. Stud. 17: 236-242.

Szkaradkiewicz A.K., T.M. Karpiński, A. Zeidler, M. Wyganowska-Świątkowska and A. Szkaradkiewicz. 2011. Protective effect of oral lactobacilli in pathogenesis of chronic periodontitis. J. Physiol. Pharmacol. 62: 685-689.

Szkaradkiewicz A.K. and T.M. Karpiński. 2013. Probiotics and prebiotics. J. Biol. Earth Sci. 3: M42-M47.

Thumm G. and F. Gotz. 1997. Studies on prolysostaphin processing and characterization of the lysostaphin immunity factor (Lif) of Staphylococcus simulans biovar staphylolyticus. Mol. Microbiol. 23: 1251-1265.

Tichaczek P.S., R.F. Vogel and W.P. Hammes. 1993. Cloning and sequencing of curA encoding curvacin A, the bacteriocin produced by Lactobacillus curvatus LTH1174. Arch. Microbiol. 160: 279-283. Toba M., H. Masaki and T. Ohta. 1988. Colicin E8, a DNase which indicates an evolutionary relationship between colicins E2 and E3. J. Bacteriol. 170: 3237-3242.

Tomita H. and D.B. Clewell. 2000. A pAD1-encoded small RNA molecule, $\mathrm{mD}$, negatively regulates Enterococcus faecalis pheromone response by enhancing transcription termination. J. Bacteriol. 182: 1062-1073.

Tomita H., E. Kamei and Y. Ike. 2008. Cloning and genetic analyses of the bacteriocin 41 determinant encoded on the Enterococcus faecalis pheromone-responsive conjugative plasmid pYI14: a novel bacteriocin complemented by two extracellular components (lysin and activator) J. Bacteriol. 190: 2075-2085.

Uchimura T. and P.C.K. Lau. 1987. Nucleotide sequences from the colicin E8 operon: homology with plasmid ColE2-P9. Mol. Gen. Genet. 209: 489-493. 
UniProtKB. 2013. Universal Protein Resource. http://www.uniprot. org/

van Belkum M.J. and M.E. Stiles. 2000. Nonlantibiotic antimicrobial peptides from lactic acid bacteria. Nat. Prod. Rep. 17: 323-365. Venema K., T. Abee, A.J. Haandrikman, K.J. Leenhouts, J. Kok, W.N. Konings and G. Venema. 1993. Mode of action of lactococcin B, a thiol-activated bacteriocin from Lactococcus lactis. Appl. Environ. Microbiol. 59: 1041-1048.

Venugopal H., P.J.B. Edwards, M. Schwalbe, J.K. Claridge, D.S. Libich, J. Stepper, T. Loo, M.L. Patchett, G.E. Norris and S.M. Pascal. 2011. Structural, dynamic, and chemical characterization of a novel S-glycosylated bacteriocin. Biochem. 50: 2748-2755.

Vignolo G., S. Fadda, M.N. de Kairuz, A.A. de Ruiz Holgado and G. Oliver. 1996. Control of Listeria monocytogenes in ground beef by 'Lactocin 705', a bacteriocin produced by Lactobacillus casei CRL 705. Int. J. Food Microbiol. 29: 397-402.

Villarante K.I., F.B. Elegado, S. Iwatani, T. Zendo, K. Sonomoto and E.E. de Guzman. 2011. Purifcation, characterization and in vitro cytotoxicity of the bacteriocin from Pediococcus acidilactici K2a2-3 against human colon adenocarcinoma (HT29) and human cervical carcinoma (HeLa) cells. World J. Microbiol. Biotechnol. 27: 975-980. Vizán J.L., C. Hernández-Chico, I. del Castillo and F. Moreno. 1991. The peptide antibiotic microcin B17 induces double-strand cleavage of DNA mediated by E. coli DNA gyrase. EMBO J. 10: 467-476.
Walterspiel J.N., S. Ashkenazi, A.L. Morrowand and T.G. Cleary. 1992. Effect of subinhibitory concentrations of antibiotics on extracellular Shiga-like toxin I. Infect. Immun. 20: 25-29.

Wescombe P.A., M. Upton, K.P. Dierksen, N.L. Ragland, S. Sivabalan, R.E. Wirawan, M.A. Inglis, C.J. Moore, G.V. Walker, C.N. Chilcott, H.F. Jenkinson and J.R. Tagg. 2006. Production of the lantibiotic salivaricin A and its variants by oral streptococci and use of a specific induction assay to detect their presence in human saliva. Appl. Environ. Microbiol. 72:1459-1466.

Wirawan R.E., K.M. Swanson, T. Kleffmann, R.W. Jack and J.R. Tagg. 2007. Uberolysin: a novel cyclic bacteriocin produced by Streptococcus uberis. Microbiol. 153: 1619-1630.

Wirawan R.E., N.A. Klesse, R.W. Jack and J.R. Tagg. 2006. Molecular and genetic characterization of a novel nisin variant produced by Streptococcus uberis. Appl. Environ. Microbiol. 72: 1148-1156.

Włodarczyk M. 2002. Phenotypic diversity of bacteria encoded by plasmids (in Polish). Kosmos. 51: 241-254.

Wolska K.I., K. Grześ and A. Kurek. 2012. Synergy between novel antimicrobials and conventional antibiotics or bacteriocins. Pol. J. Microbiol. 61: 95-104.

Worobo R.W., T. Henkel, M. Sailer, K.L. Roy, J.C. Vederas and M.E. Stiles. 1994. Characteristics and genetic determinant of a hydrophobic peptide bacteriocin, carnobacteriocin A, produced by Carnobacterium piscicola LV17A. Microbiology. 140: 517-526. 